\title{
ARAMEJSKA WERSJA KSIĘGI AMOSA W TARGUMIE JONATANA
}

Aramejski przekład Księgi Amosa wchodzi w skład Targumu do Proroków Mniejszych ${ }^{1}$ i jest częścią targumu do ksiąg prorockich, ${ }^{2}$ zwanego Targumem Jonatana. ${ }^{3}$ Przekład ten został oficjalnie uznany przez wspólnoty żydowskie mieszkające w Babilonii. Samo powstanie Targumu Jonatana było jednak kwestią procesu i nadal trudno dać precyzyjną odpowiedź na pytanie o jego początki. Przyjmuje się, że datowanie kompozycji Targumu Jonatana przypadało pierwotnie na okres przed 135 r. po Chr., choć jest sprawą dyskusyjną, czy przed, czy też po 70 r. po Chr., następnie doczekała się rewizji. ${ }^{4}$

Zasadnicze cele, jakie przyświecały aramejskim tłumaczom, polegały na tym, że mieli oni przekazać taki przekład Pisma Święł tego, który miał być zrozumiały i jasny dla przeciętnego słuchacza

1 Zbiór 12 (hebr. תרי עשר ) był uważany za jedną księgę.

2 Targum do Proroków obejmuje to księgi proroków wcześniejszych (Joz, Sdz, 1-2Sm i 1-2Krl) i proroków późniejszych (Iz, Jr, Ez i dwunastu proroków).

3 Tradycja żydowska łączy to dzieło z Jonatanem ben Uzzielem, uczniem Hillela Starszego, który według tradycji miał go otrzymać od proroków okresu powygnaniowego: Aggeusza, Zachariasza i Malachiasza (b. Meg. 3a). W innym miejscu Talmud Babiloński łączy tytuł tego dzieła z uczonym żyjącym w IV w., Józefem z Pumbedity, odwołuje się jednak do Targumu do Proroków jako do już ustalonej tradycji interpretacyjnej, dzięki której był w stanie np. ustalić znaczenie Za 12,11 (b. Meg. 3a; b. MQ 28b). K. J. C a t h c a r t, R. P. G or d o n, The Targum of the Minor Prophets, AB 14, Edinburgh 1989, s. 1.

4 M. M c N a m a r a, Interpretation of Scripture in the Targumim, w: A. J. H a u s e r, D. F. W a t s o n (red.), A History of the Biblical Interpretation, t. 1: The Ancient Period, Grand Rapids, Mi. 2003, s. 168. S. H. L e v e y, The Date of Targum Jonathan to the Prophets, VT 21/1971, s. 186-196, wskazuje, że miało to miejsce między III a V w. na terenie Babilonii. Na ten temat szerzej zob. K. J. C a t h c a r t, R. P. G o r d o n, The Targum of the Minor Prophets, s. 18. 
lub czytelnika, a jednocześnie tłumaczenie powinno być zgodne ze współczesnymi im koncepcjami i interpretacjami przesłania Biblii. W tym celu stosowano różnego rodzaju techniki translatorskie. Wprowadzano np. standardowe słowa i zwroty, szczególnie w tych miejscach, w których wersja hebrajska nie była zbyt czytelna, lub też uznawano za konieczne zmianę metaforycznego znaczenia danego zwrotu w coś bardziej zrozumiałego. ${ }^{5}$ Targumiści dokonywali „aktualizacji”, w ten sposób w tekstach biblijnych pojawiają się informacje o miejscach, instytucjach, a nawet wydarzeniach, które należą do okresu znacznie późniejszego niż ich własny. ${ }^{6}$ Tłumacze aramejscy starali się tak przekazać tekst biblijny, aby był on zgodny z aktualnymi poglądami, które na ogół były zgodne z poglądami rabinów.

Prezentowane niżej omówienie dotyczy aramejskiej wersji Księgi Amosa, proroka, który żył w połowie VIII w. przed Chr. i był uznawany za pierwszego spośród tzw. proroków piszących, ponieważ jego wyrocznie zachowały się $\mathrm{w}$ formie spisanej. ${ }^{7}$ Targum Księgi Amosa, podobnie jak pozostałe aramejskie tłumaczenia ksiąg zbioru Dwunastu, wpisuje się w nurt żydowskiej interpretacji tej księgi na przełomie naszych er.

W artykule zostaną wskazane charakterystyczne aspekty natury przekazu Księgi Amosa w przekładzie aramejskim, ${ }^{8}$ a szczególnie dotyczące zmian w tłumaczeniu, które wynikają z przyczyn teologicznych.

5 Tamize, s. 2.

6 Tamże.

7 W Biblii rabinicznej Księga Amosa znajduje się na trzecim miejscu w zbiorze Dwunastu Proroków.

8 W języku angielskim ukazało się opracowanie i przekład Targumu Jonatana wydane w pięciu tomach w ramach serii Aramaic Bible. The Targums (t. 10-14), ostatni z nich to Targum Dwunastu Proroków Mniejszych opracowany przez K. J. Carthcarta i R. P. Gordona, w którym znajduje się angielski przekład Targumu Amosa; zob. tamże, s. 77-96. 


\section{Prorok Amos w targumie}

Podobnie jak w kilku pozostałych księgach ze zbioru Dwunastu Proroków, Księga Amosa rozpoczyna się od tytułu, w którym znajdują się informacje na temat proroka oraz odniesienia historyczne do czasów, w których działał: ${ }^{9}$

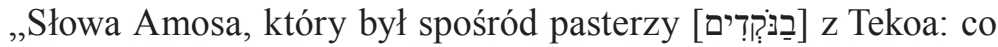
widział [חזָזה] w sprawie Izraela, za dni Ozjasza, króla Judy, i za dni Jeroboama, syna Joasza, króla Izraela, na dwa lata przed trzęsieniem ziemi" $(1,1)$

W aramejskiej wersji tekst ten został doprecyzowany w następujący sposób:

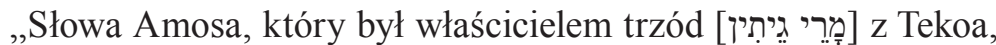
które prorokował [דָאִתנַברי] o Izraelu, za dni Ozjasza, króla pokolenia

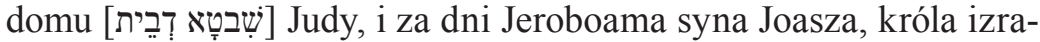

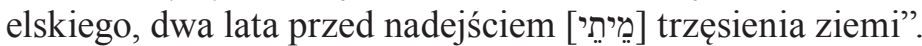

W tytule hebrajskim Amos zostaje nazwany „pasterzem” przy użyciu rzadko stosowanego słowa נקי ${ }^{10}$ Nieco inaczej czyni sam prorok w 7,14, gdzie nazywa siebie בְּקָ to jest ,hodowcą bydła". ${ }^{11}$ Jednak w targumie Amos został nazwany ,właścicielem trzód” (מָרֵา (גֵיתִין zarówno w tytule księgi, jak i w 7,14.

W tekście masoreckim zwraca też uwagę użycie czasownika ,widział” (דָזָז), na określanie tego, co doświadczał prorok Amos. Tłumacz aramejski w tym miejscu wprowadza jednak dokładny termin „prorokować”, od rdzenia נבי, opisując bezpośrednio misję prorocką Amosa, choć on sam nie chciał się nazywać prorokiem.

9 Por. np. Oz 1,1; So 1,1; Ha 1,1.

10 Na oznaczenie ,pasterza” zazwyczaj w języku hebrajskim używa się słowa ro'eh (zob. np. Am 1,2; 3,12). W języku ugaryckim temu terminowi odpowiada słowo określające pewien typ kapłana lub osobę oficjalnie związaną ze świątynią. W Biblii Hebrajskiej terminem tym określono Meszę, króla Moabitów, który jako „hodowca trzód”, miał obowiązek składania królowi Izraela daninę w postaci stu tysięcy owiec i wełny ze stu tysięcy baranów $(2 \mathrm{Krl} 3,4)$.

11 Tłum. BT: ,pasterzem”. 
Warto zwrócić uwagę jeszcze na dwie charakterystyczne zmiany w przekładzie aramejskim tytułu. Pierwsza z nich to dodanie do tekstu masoreckiego, charakterystycznego dla Targumu Jonatana, zwrotu שִבטָטא דְברית (,pokolenia rodu /dosł. domu/") oraz dodanie rdzenia את o znaczeniu ,przychodzić”, „,nadchodzić” (hafel), którego nie ma w tekście hebrajskim. Zabieg ten był stosowany w celu doprecyzowania tekstu hebrajskiego.

Na temat sytuacji życiowej proroka dowiadujemy się także w Am 7, kiedy to prorok sam mówi o swoim pochodzeniu i swojej misji.

Tekst maasorecki 7,14-16:

${ }^{14}{ }^{14}$ odpowiedział Amos Amazjaszowi: Nie jestem ja prorokiem

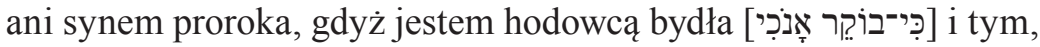

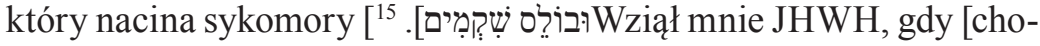
dziłem] za trzodą i rzekł do mnie JHWH: «Idź, prorokuj do ludu

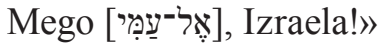

${ }^{16}$ Teraz więc słuchaj słowa JHWH! Ty mówisz: «Nie prorokuj

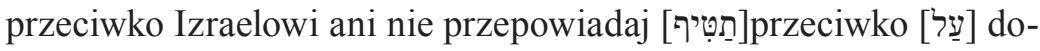
mowi Izaaka!»”".

Targum Am:

${ }^{14}$ I odpowiedział Amos Amazjaszowi: „Nie jestem ja prorokiem

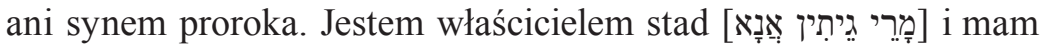

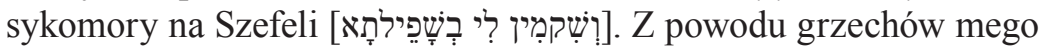

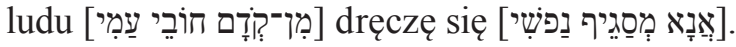

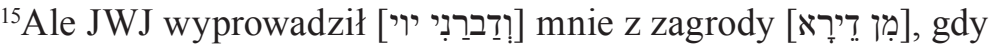

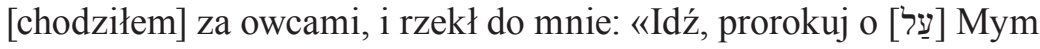
ludzie Mym, [עַל עַבְִ Izraelu».

${ }^{16}$ Teraz więc słuchaj słowa JWJ. Ty, mówisz: «Nie prorokuj o [לעל]

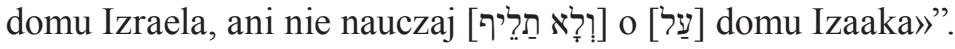

W tekście masoreckim w 7,14 użyto hebrajskiego terminu בקִpasterz bydła” lub „hodowca bydła”). Następnie prorok mówi o sobie,

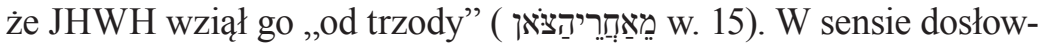
nym wyrażenie to mogło oznaczać „kogoś kto [chodził] za trzodą”, jednak używano go również w znaczeniu teologicznym, na przykład 
w odniesieniu do wybrania Dawida (zob. 2Sm 7,8). Hebrajski termin בוֹקֵ (,hodowca bydła”) w targumie został przetłumaczony jako

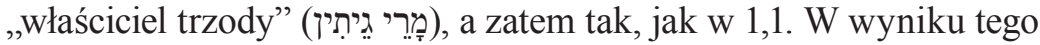
ujednolicenia targumista uniknął niekonsekwencji w opisie sytuacji życiowej proroka. ${ }^{12}$ Tłumacz podał także dodatkowe informacje na temat drugiego zajęcia proroka, o którym wspomina sam prorok, mówiąc, że jest „nacinającym sykomorę”. W tym przypadku targum określa Amosa analogicznie do poprzedniego terminu „właścicielem sykomor", uzupełniając informacją o położeniu pola z drzewami, które mają znajdować się „na Szefeli”. Ten dodatek jest interpretowany jako świadectwo „ekonomicznej geografii czasów talmudycznych” (por. b.Ned. 38a). ${ }^{13} \mathrm{O}$ ile tekst masorecki kończy się na tym określeniu, to w targumie prorok mówi jeszcze o tym, że „dręczy samego siebie”, co w praktyce oznacza stosowanie postu. Prorok dodaje też, że czyni to za grzechy ludu. Takie znaczenie tego wyrażenia może wynikać z interpretacji polecenia Amazjasza, który zwraca się w lekceważący sposób do Amosa: ,idź... jedz chleb” (w. 12). W tym kontekście może to świadczyć o tym, że prorok nic nie jadł w tym czasie. ${ }^{14}$

W w. 15 meturgeman inaczej przedstawia sytuację nadania misji prorokowi. W tekście masoreckim Amos stwierdza, że JHWH, go „wziął, gdy [chodził] za trzodą", natomiast targum thumaczy to jako „wyprowadził z zagrody”. Użycie takiego sformułowania w wersji aramejskiej może wskazywać na tryb życia proroka, który bardziej odpowiada określeniu „właściciel trzód”.

W tekście hebrajskim w. 16 występuje przyimek עַ, który większość współczesnych tłumaczeń rozumie w sensie „przeciw”, „przeciwko”. Jednak w targumie jest on odczytany jako „o”, co sugeruje w. 15.

12 K. J. C a t h c a r t, R. P. G o r d o n, The Targum of the Minor Prophets, s. 77, przyp. 1.

13 Początek formularza (dół formularza) L. S m o la r, M. A b e r b a c h, Studies in Targum Jonathan to the Prophets i P. C h u rg i n, Targum Jonathan to the Prophets, Library of Biblical Studies, New York-Baltimore 1983, s. 111 przyp. 303. Por. M. S o k o 1 o ff, A Dictionary of Jewish Babylonian Aramaic, Ramat Gan, Baltimore-London 2002, s. 136.

14 K. J. C a t h c a r t, R. P. G or d o n, The Targum of the Minor Prophets, s. 2. 
W tekście masoreckim występuje czasownik נָָטֵ w formie hifil, który tutaj ma znaczenie ,przepowiadać”, ,głosić”. Tekst targumu zamienia

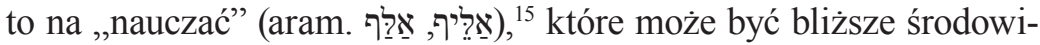
skom, gdzie studiowano Biblię Hebrajską. W wersecie tym targumista dodał także słowo „dom” przed nazwą własną Izrael, podobnie jak to jest na końcu zdania, kiedy jest mowa o „domu Izaaka”. Dodanie tego terminu to jedna z charakterystycznych zmian jakie stosują targumiści.

\section{Aktualizacja tekstów biblijnych}

Zjawisko aktualizacji dotyczy różnych spraw, $m$. in. często miejscowości, znane z ksiąg Biblii, w targumach noszą inne nazwy, zazwyczaj o wiele późniejsze niż biblijne. Podobnie jeśli chodzi o pewne instytucje, o których nie ma wzmianek w Biblii, a pojawiają się w przekładach aramejskich. Bezpośrednim celem takiego postępowania było to, by Pismo bardziej odpowiadało współczesnej sytuacji, oraz wywołanie przekonania, że instytucje, wydarzenia i doświadczenia ludzi epoki targumów są w jakimś sensie częścią Biblii. Jedną z takich instytucji, o której istnieniu wielokrotnie jest mowa w targumach jest synagoga. Targum Księgi Amosa wspomina instytucję synagogi trzykrotnie

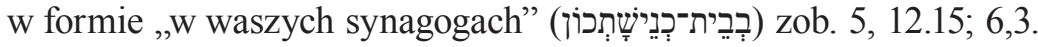
W tekście masoreckim w tych wersetach jest mowa o miejscu, gdzie

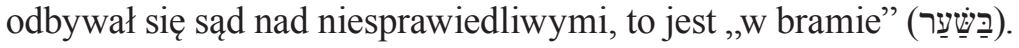

Tekst masorecki 5,12b:

„(...) uciskacie sprawiedliwego, łapówkarze, a ubogich gnębicie

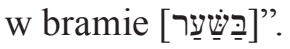

Targum 5,12:

„(...) prześladujecie niewinnego, by przez oszustwo zdobyć pieniądze i wypaczacie sprawę człowieka w potrzebie w swoich

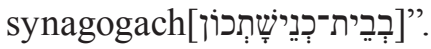

15 Por. Tg Ps 18,35; Tg Prz 11,25, Koh 9,10; zob. M. J a s t r o w, A Dictionary of the Targumim, the Talmud Babli and Yerushalmi, and the Midrashic Literature and II, t. I, London-New York 1903, s. 72. 
Tekst masorecki 5,15a:

„Miejcie w nienawiści zło, a miłujcie dobro! Ustanawiajcie sąd

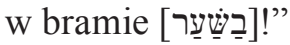

Targum 5,15a:

„Miejcie w nienawiści czynienie zła, a miłujcie czynienie dobra!

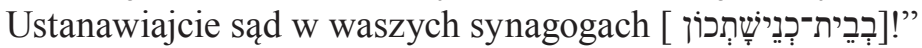

W czasach biblijnych miejscem, gdzie rozstrzygano sądowe sprawy, były bramy. Jednak w okresie talmudycznym bramy zostały zastąpione synagogami. To w nich zbierała się społeczność żydowska, aby wymierzać sprawiedliwość (por. ww. 12.15). Możliwe też, że tłumacz, zmieniając „bramę” na „synagogi”, chciał podkreślić, że instytucja synagogi pojawiła się już na wczesnym etapie historii Izraela, wyrażając w ten sposób powszechnie przyjęty pogląd wśród Żydów. ${ }^{16}$

Warto jednak zaznaczyć, że „brama” została jeszcze inaczej przetłumaczona w 5,10a

Tekst masorecki:

„Nienawidzą w bramie, tego który karze (...)”

Targum:

„Nienawidzą tego, który napomina ich w sądzie [בית דִיָָ ]

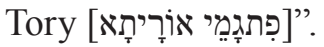

Tym razem termin „brama” zostaje zastąpiony instytucją o nazwie bet din, to jest „sąd”. Dodatkowo w targumie jest mowa o słowach Tory, która ma już w tym kontekście wyraźny autorytet. W kontekście Tory, Prawa pojawia się jeszcze inna aktualizacja, mianowicie jest też wprowadzenie do tekstu tłumaczenia słowa „nauczyciele” (aram. מַלְפִין), np. Am 2,11-12:

Tekst masorecki:

${ }^{11}$ „Niektórych spośród waszych synów wzbudzałem na proroków, a spomiędzy waszych młodzieńców - nazirejczyków (...). ${ }^{12}$ A wy s. 106.

${ }^{16}$ L. S m o l a r, M. A b e r b a c h, Studies in Targum Jonathan to the Prophets, 
dawaliście pić nazirejczykom wino i prorokom rozkazywaliście: «Nie prorokujcie!»"

Targum:

${ }^{11}$ „Niektórych z waszych synów wzbudziłem na proroków, a niektórych z waszych młodzieńców na nauczycieli. ${ }^{12} \mathrm{Wy}$ jednak waszych nauczycieli zwiedliście winem, a prorokom rozkazywaliście mówiąc: "Nie prorokujcie»."

W tekście masoreckim w ww. 11 i 12 jest mowa o ,nazirejczykach", natomiast targum używa w tym miejscu słowa „nauczyciele”. Smolar i Aberbach uważają, że chodzi tu o poglądy panujące wśród rabinów, którzy podejście do ślubów uważali za nierozważne. ${ }^{17}$ Dlatego też przy tłumaczeniu Am 2,11n. targumista musiał znaleźć sposób na zignorowanie nazirejczyków, ślubujących nie pić wina, a których tekst masorecki miał w dużym poważaniu. Wprowadza zatem termin zastępczy „,nauczyciele”, którzy nauczają Prawa, a zatem mają także dość ważną pozycję w społeczności żydowskiej.

W targumie o nauczycielach jest też mowa w 5,13. Tekst masorecki

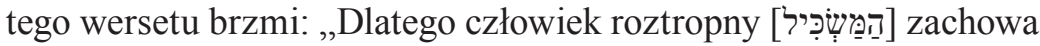
milczenie”. Meturgeman w tym miejscu mówi jednak o „nauczycielach", podkreślając w ten sposób przekonanie o znaczeniu studiowania i randze nauczycieli w czasach talmudycznych. ${ }^{18}$

\section{Zmiany w przekazie idei teologicznych Targumu Amosa}

W Targumie Amosa, podobnie jak w całym Targumie Jonatana, aramejscy tłumacze starają się przekazać pewne poglądy teologiczne, których brak w tekście masoreckim księgi. Stosują oni zmiany w przekładzie aramejskim, które odzwierciedlają wielki szacunek do Boga, podkreślają jego jedyność, czy ukazują jego przymioty.

17 Tamże, s. 9.

18 Smolar i Aberbach próbują ustalić, czego dotyczy aluzja zawarta w ostrzeżeniu: ,zachowajcie milczenie przed grzesznikiem”, i uważają, że może tu chodzić albo o prześladowania w czasach Antiocha IV lub Hadriana, albo o ucisk panujący w czasach sprawowania urzędu przez Judę II w III w. po Chr.; tamże, s. 102. 
Bóg Izraela jest nazywany w targumie imieniem własnym, które w tekście aramejskim zapisywane jest trzema spółgłoskami JWJ w miejsce hebrajskiego tetragramtonu JHWH. Meturgeman stosuje także

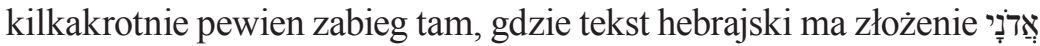

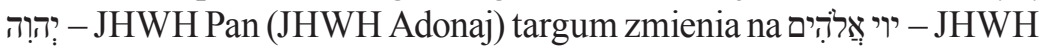
Bóg (JHWH Elohim, podobnie we współczesnych tłumaczeniach „Pan Bóg”). Takie zastąpienie zdarza się dość często w Targumie Amosa oraz pozostałych (zob. Am 1,8; 3,8.11.13; 4,2.5 i in.). ${ }^{19}$

W odniesieniu do opisów Boga aramejscy tłumacze wykazują skłonność do odrzucania antropomorficznych wyrażeń odnoszących się do Boga.

W Targumie Amosa zmiana taka występuje w tłumaczeniu w Am 9,8a:

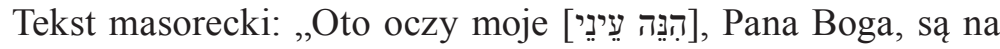
królestwo grzeszne (...)".

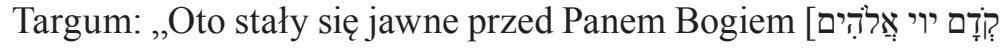
]גְר uczynki grzesznego królestwa (...)".

Wyrażenie „moje oczy” zamieniono na typową konstrukcję stosowaną przez tłumaczy aramejskich, która składa się z czasownika w formie biernej „czynić jawnym”, „objawiać” (aram. גלי ) w złożeniu

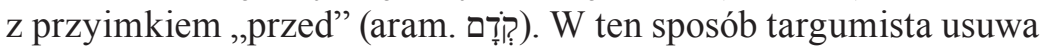
antropomorfizm, mówiący o Bożych „oczach”.

Podobnie tłumacz pomija antropomorfizm w przekładzie wypo-

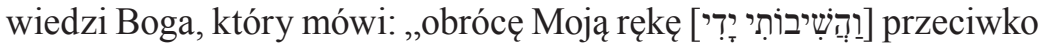
Ekronowi” $(1,8 b)$, tłumacząc tę frazę jako „bicz Mojej mocy zwrócę

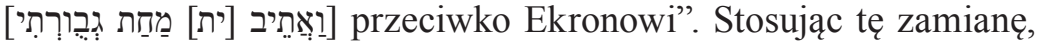
tłumacz usuwa antropomorfizm, mówiący o ręce Boga i zastępuje go powszechnie przyjętym symbolicznym znaczeniem tego terminu. W Biblii Hebrajskiej dość często ręka jest właśnie symbolem mocy Boga. $^{20}$

19 Por. Mi 1,2; So 1,7; Za 9,14.

${ }^{20}$ Można je znaleźć szczególnie często w tekstach biblijnych ukazujących wyjście Izraela z Egiptu. 
Zgodnie z zasadniczym przekonaniem religijnej myśli żydowskiej, Targum Jonatana podkreśla, że wszystko, co dzieje się na świecie, Bóg ma pod kontrolą, zarządza tym i tak naprawdę sam to wywołuje. W tym celu często zmienia się formę czasownika użytą w tekście masoreckim na taką, która nie budzi żadnych wątpliwości i wskazuje na kontrolowanie przez Boga wydarzeń rozgrywających się w historii. Tłumacz zapobiega także powstaniu wrażenia, jakoby Bóg ponosił bezpośrednią odpowiedzialność za nieszczęścia, które spotykają mieszkańców miasta:

Tekst masorecki 3,6b:

„(...) Czyż zdarza się w mieście nieszczęście, by JHWH tego nie sprawił?"

Targum:

„(...) czy przychodzi na miasto nieszczęście, jeśli [wpierw] nie

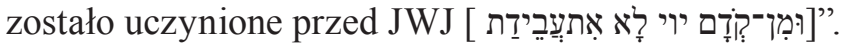

Fraza z tekstu masoreckiego: „Pan tego nie sprawił” zostaje zmieniona ze względu na działanie Boga. Targumista realizuje zamierzony cel, stawiając czasownik w stronie biernej i posługując się przyim-

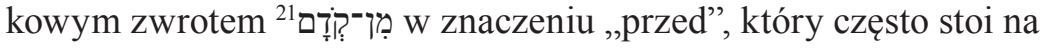
straży godności i pozycji Boga.

Inną techniką stosowaną przez tłumaczy aramejskich w mówieniu o Bogu było wprowadzanie terminów zastępczych. Targumiści unikali mówienia w sposób bezpośredni o działaniu Boga lub jego odczuciach, wprowadzając termin memra.

Tekst masorecki: 1,2:

«I powiedział on: JHWH zagrzmi z Syjonu. Z Jeruzalem wyda Swój głos, a lamentować będą łąki pasterzy i szczyt Karmelu uschnie».

${ }^{21}$ Szerzej na temat użycia tego przyimka w targumach zob. M. L. K 1 e i $n$, The Preposition QDM (before) a Pseudo-anti-Anthropomorphism in the Targums, JTS 36/1979, s. 502-507. Jak zauważył M. L. Klein, qdm pełni rolę nie tyle anty-antropomorficzną, ile raczej ma wyrażać szacunek i poważanie - analogicznie w samym aramejskim biblijnym przyimek ten występuje w związku z królami i ich dworzanami, którym towarzyszą różne działania (Ezd 4,18; 7,14; Dn 2,10; 5,17). 


\section{Targum:}

„I powiedział: «JWJ woła z Syjonu. Z Jerozolimy Swoje memra [ מֶיְמֶריה podnosi z Jerozolimy; siedziby królów zostaną zburzone, a ich potężne miasta zniszczone»".

W tym przypadku termin memra zastępuje hebrajskie słowo „głos”, a zatem tłumacz oddaje literalnie znaczenie tekstu hebrajskiego.

W przekładzie tego wersetu zachodzą także inne zmiany, na które warto zwrócić uwagę. Tłumacz używa w kontekście aktywności Boga czasownika „wołać” (יכלי- hafel), który lepiej brzmi w odniesieniu do Boga niż hebrajski ,grzmieć”, „ryczeć”.

W tekście targumu zmieniona zostaje także druga część wersetu. Targum utożsamia pasterzy z królami i opisuje sytuację, w której Bóg podnosi głos i pustoszy zamki królów i ich warownie. Taka prezentacja nie zgadza się z przekazem tekstu masoreckiego, gdzie mowa jest o skutkach interwencji Bożej na ziemi urodzajnej i polach. Ponadto tłumacz używa „mieszkania”, „siedziby” jako odpowiedników „pastwiska” oraz nie uznaje hebrajskiego terminu „Karmel”, jako nazwy miejsca (podobnie w 9,3).

Inne przykłady na wprowadzenie terminu memra w targumie:

Tekst masorecki 4,11:

„Zniszczyłem was, jak Bóg zniszczył Sodomę i Gomorę; staliście się jak głownia wyciągnięta z ognia; ale do Mnie [עָּ] nie wróciliście - wyrocznia JHWH”.

Targum:

„Moje memra [מִימְרִ [ִ ogarnęło obrzydzenie do was, jak JWJ nabrał wstrętu do Sodomy i Gomory, byliście jak głownia wyjęta z ognia,

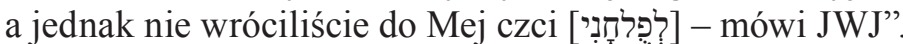

Uczeni przyjmują, że memra w targumach to nie personifikacja albo hipostaza, lecz rzeczownikowe określenie zastępcze. ${ }^{22} \mathrm{~W}$ ara-

22 Pochodzenia memra trzeba szukać np. w sformułowaniach typu: „Słowem Pańskim stworzone zostały niebiosa, wszystkie ich zastępy oddechem ust Jego" (Ps 33,6). Paralele tej idei znajdują się też w stwierdzeniach literatury wczesnorabinackiej typu: „Dziesięcioma wypowiedziami stworzony został świat” (m. Abot 1) 
mejskich przekładach memra pojawia się jako podmiot zdania w zastępstwie Bożego imienia lub jako zaimek w niemal wszystkich możliwych kontekstach. W 6,8 występuje w formule: „JWJ Bóg poprzysiągł na swoje memra”, które zastępuje frazę „Poprzysiągł JHWH Pan na samego siebie ..." W rozdziale dziewiątym memra występuje kilkakrotnie. W 9,2 jest użyte dwukrotnie. Na początku wersetu w wypowiedzi Boga: „Moje memra wywiedzie ich” (tzn. ludzi z Szeolu), które w wersji hebrajskiej jest takie „Moja ręka zabierze ich". Aby nie powstało wrażenie antropomorfizmu, targumista używa strony biernej i wprowadza memra jako pośrednika Bożego działania. Termin ten powraca w końcowej części zdania, kiedy jest mowa o tym, że z wysokich budynków „sprowadzi ich Moje memra”, które jest tłumaczeniem ,stamtąd ich sprowadzę”. W 9,3 pojawia się w kontekście ukrycia się ludzi: ,gdyby przed Moim memra ukryli się wśród morskich wysp", które jest aramejską wersją tekstu hebrajskiego ,przed Moim wzrokiem na dnie (morza)”. Następnie termin ten występuje także w 9,4: ,pobudzę Moje memra przeciw nim za zło, nie za dobro"', który zostaje tu wprowadzony, aby nie powielać antropomorficznego języka tekstu masoreckiego ,skierują na nich Moje oczy przeciw nim za zło, nie za dobro".

Podobnie jak memra, tłumacze aramejscy używali słowa szechina jako terminu zastępczego. Za jego pośrednictwem wyrażali przekonanie o Bożej obecności wśród Jego ludu, a jednocześnie niczego nie ujmowali najważniejszej z prawd: o Jego transcendencji. Gdy tekst biblijny mówił o Bogu, że mieszka ze swym ludem lub przebywa w świątyni, Targum zawsze ukazuje Go jako Tego „który sprawił, że Szechina Jego chwały zamieszkała w twierdzy wyniosłej i ustanowił swe zgromadzenie na ziemi, który rozkazał zgromadzić wojska liczne jak morskie wody i rozprasza je po obliczu ziemi - Pan jest Jego imię" (Tg Am 9,6).

oraz w błogosławieństwie liturgicznym: „Ten, który swoim słowem stworzył niebiosa" (b. Sanhedrin 42a); t e n ż e, Anthropomorphism and Anthropopathism in the Targums of the Pentateuch, Jerusalem 1982, s. 172. 
W tekście masoreckim jest mowa o tym, że Bóg „buduje swą izbę w niebiosach". Wersja targumu może odzwierciedlać pogląd, że Szechina mieszka w niebie, a nie na ziemi. ${ }^{23}$

Tłumacze aramejscy byli wyczuleni na niewłaściwe wyobrażenia o Bogu. W tym celu stosowali kluczowe terminy pojęcia teologiczne. Każde stwierdzenie potencjalnie narażone na błędne zrozumienie stało się przedmiotem przemodelowania w takim zakresie, jaki wydawał się niezbędny do zaakceptowania od strony teologicznej. $\mathrm{Na}$ przykład. wypowiedź Boga skierowana do Izraela przez Amosa w 3,2:

Tekst masorecki:

„Tylko was znałem ze wszystkich narodów [dosł. „rodzin”] na ziemi, dlatego was nawiedzę karą za wszystkie wasze winy.”

Targum:

„Wśród wszystkich rodzin na ziemi tylko was pragnąłem, dlatego ukarzę was za wszystkie wasze grzechy".

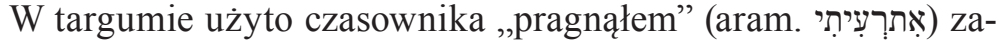

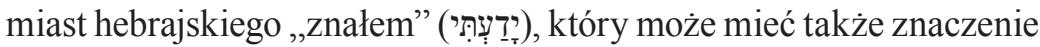
„wybrałem” lub „troszczyłem się”. W ten sposób targumista unika potencjalnego ograniczenia Bożej wiedzy o narodach, które mógłby sugerować tekst odczytany literalnie.

Tłumacze aramejscy nie akceptują również jakiegokolwiek łączenia zła z Bogiem i bez wahania cenzurują nie odpowiadający temu poglądowi fragment, jak np. w Am 3,6, gdzie dokonana zmiana jest drobna, ale widocznie wystarczająca: „Czy może być zło w mieście, które by nie było uczynione przed Panem?" zamiast hebrajskiego „Czyż może być w mieście nieszczęście, by Pan tego nie sprawił?”

Będąc wszechwiedzący, Bóg nie musi „spoglądać” na ludzi, ani tym bardziej samemu ich szukać. Targum Am 9,3a: „I wyznaczę tych, którzy będą szukali”. Kiedy człowiek woła o pomoc, jest czymś

23 Jednak według J1 2,27; 4,17; Za 2,14n.; 8,3 Szechina przebywa razem z Izraelem; zob. K. J. C a th c a r t, R. P. G ord o n, The Targum of the Minor Prophets, s. 96 . 
ewidentnie niewłaściwym mówić, że Bóg wysłuchuje lub nie wysłuchuje, zatem także że odpowiada lub nie. Poza nielicznymi wyjątkami Boże „wysłuchanie” lub „odpowiedzenie” w Targumie Jonatana przybiera postać ,„przyjęcia modlitwy”.

Teologiczna ortodoksja Targumu do Proroków wyraża się również w trosce o unikanie choćby cienia nieprawidłowości w sprawach kultycznych.

Tłumacze aramejscy starali się, by nie zostawić cienia wątpliwości, że bałwochwalstwo jest rzeczywistością w najwyższym stopniu bezużyteczną i grzeszną, pociągającą za sobą surowe konsekwencje. Targumiści w swoich przekładach wyraźnie podkreślają kontrast między ołtarzem Pańskim a ołtarzem Baala; zob. Am 2,8; 3,14.

Tekst masorecki 2, 8:

„Na szatach [wziętych] w zastaw wylegują się przy każdym ołta-

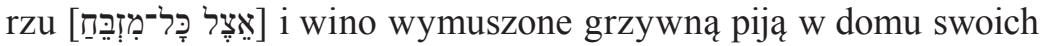

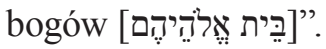

Targum:

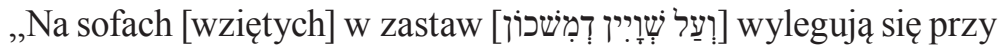

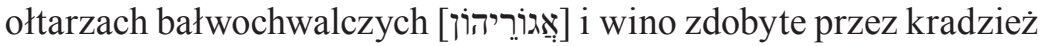

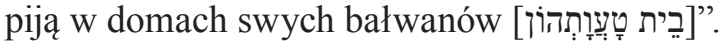

Przekład tego wersetu różni się od wersji hebrajskiej. Po pierwsze tłumacz zmienił nieco opis sytuacji, mówiąc o „sofach”, a nie „szatach”. Zmiana ta prawdopodobnie wynika z tego, że szaty były rozścielone na sofach. W tekście masoreckim jednak wyraźnie akcentuje się fakt, że biedakom złośliwie zatrzymywano część ich ubrania. Jednak charakterystyczne zmiany w targumie dotyczą ukazania kultu bałwochwalczego. Podobnie, jak w innych miejscach, tłumacz zastosował tu charakterystyczne słownictwo, mianowicie ołtarze bałwochwalcze nazywa „stos (kamieni)” (aram. איגוֹר) zamiast ,oktarz" (hebr. מִדבְָזָא użyte jest stałe określenie w odniesieniu do bóstw, bałwany, idoli, (,błędy”, aram. טעו), a nigdy „bogowie” (אֶלהִים).

24 Por. np. Oz 8,11; 10,1n.8. 
Tekst masorecki 3,14:

„(...) że w dniu, kiedy będę karał występki Izraela, ukarzę [rów-

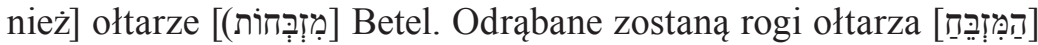
i upadną na ziemię".

Targum:

„(...) że w dniu, kiedy będę karał grzechy Izraela, ukarzę [również]

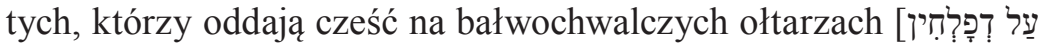

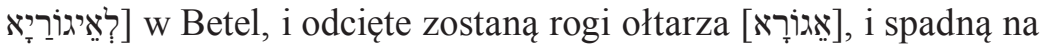
ziemię".

Targum Amosa przedstawia bałwochwalstwa zgodnie z przekonaniami religijnymi, które są przekazane w całym Targumie Jonatana. Bałwochwalstwo jest grzechem i doznaje zrównania z wszystkimi innymi grzechami. ${ }^{25}$ Nieuchronna kara spotka Izraela za niewybaczalną winę - utrata wolności, przepadek majątku na rzecz wrogów Izraela $\mathrm{i}$ wygnanie z ziemi rodzinnej.

Z perspektywy okresu talmudycznego prawdziwa idolatria już dawno przestała stanowić zagrożenie dla przetrwania judaizmu, ale w czasach prześladowań mogła zachwiać ludźmi o słabym charakterze, którzy mogli ulec ułudzie zewnętrznego blasku i pozbawionego granic hedonizmu świata pogańskiego.

W związku z tym targumiści walczyli z wszelkimi interpretacjami Pisma Świętego, które mogłyby zwieść prosty lud uczęszczający na nabożeństwa synagogalne i przysłuchujący się czytaniom biblijnym i zasiać niepokój, że w bałwochwalstwie mimo wszystko może kryć się coś wartościowego, a świat pogański może nie być na wskroś zły, że idole nie są aż tak martwe, jak się je przedstawia, lecz mogą w nich

25 Zob. też Tg. Am 4,4-5: „Przybyli do Betel i zbuntowali się, w Gilgal pomnożyli swój grzech, każdego ranka przynosząc ofiary, dziesięciny co trzeci dzień. Ofiarę dziękczynną zabieracie przemocą i przynosicie ją z pieśnią, mówiąc: «To jest na ofiarę»”. Targum zmienia ironiczne wezwanie TM „przyjdźcie do Betel i grzeszcie, do Gilgal i grzeszcie jeszcze więcej”. Może chodzić tu o to, by JHWH nie był łączony z jakimkolwiek nawoływaniem do zła. Konsekwentnie imperatywy z TM „przynieście”, „spalcie” są użyte przez targumistę w innej formie. 
tkwić jakieś ukryte, tajemnicze siły, zaś bożki pogańskie mogą swym wyznawcom zapewniać wymierne korzyści. ${ }^{26}$

W tym kontekście warto też zwrócić uwagę na krytykę nadawania obcych imion wśród Żydów, o której wspomina Targum Amosa 6,1:27

„Biada tym, którzy są beztroscy na Syjonie, i tym, którzy są pewni siebie w mieście [TM: „na wzgórzu”] Samaria, którzy swoim dzieciom nadają imiona dzieci [obcych] narodów i którzy uważają, że dom Izraela zależy od nich".

Targumista dodaje do tekstu hebrajskiego sprzeciw wobec nadawania dzieciom obcych imion, który jest reakcją na rozszerzanie się obcych wpływów, szczególnie wśród wyższych sfer narodu żydowskiego. Możliwe, że sprzeciw ten jest odzwierciedleniem tendencji hellenizacyjnych. ${ }^{28}$

Izrael, którego widzi targumista, jest utożsamiany z grupą wiernych, którzy przestrzegają Tory lub stają się nią. Tak jak w innych miejscach Targumu do Proroków, mówi się o nawróceniu do JHWH, tu kładzie się nacisk na nawrócenie na Torę. Według rabinów, Tora to najlepsze antidotum na grzech, to zdanie w pełni podziela Targum Jonatana, wielokrotnie podkreślając rangę i znaczenie studiowania i nauczania Tory. ${ }^{29}$

Postępować słusznie to nie tylko studiować Torę, ale także jej przestrzegać, a ci, którzy „gromadzą ucisk i nieprawość w swoich pałacach” (Am 3,10b), bo „nie wiedzą, jak dobrze postępować” (Am 3,10a), są w Targumie Amosa ukazani jako ludzie, którzy „nie wiedzą, jak spełniać przykazania Tory”. Natomiast od ich wypełniania lub nie zależy ocalenie. s. 150 .

${ }^{26}$ L. S m o l a r, M. A b e r b a c h, Studies in Targum Jonathan to the Prophets,

27 TM: „Biada beztroskim na Syjonie i zadufnym na górze Samarii, wasi dostojnicy pierwszego spośród narodów, do którego przychodzi cały dom Izraela".

${ }_{28}$ Zob. K. J. C a th c a r t, R. P. G o r d o n, The Targum of the Minor Prophets, s. 88 .

29 Na temat znaczenia Prawa zob. też Tg Am 3,10; 5,10. 
Tekst masorecki 9,1:

„Widziałem Pana, stojącego nad ołtarzem, i rzekł: «Uderz w głowicę i niech zadrżą wiązania dachu, i niech spadną na głowy wszystkich! Pozabijam mieczem pozostałych, nie umknie $\mathrm{z}$ nich żaden, co ucieka, ani nie ocaleje z nich żaden, co się ratuje»" ".

Targum:

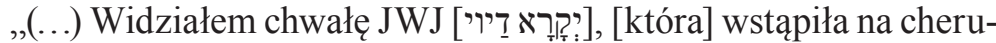
binie i spoczęła na ołtarzu; JHWH rzekł: «Jeśli Mój lud dom Izrael nie powróci do Tory [לְארָּרָא], zgaś lampę; król Jozjasz zostanie zabity, świątynia będzie obrócona w perzynę, dziedzińce świątyni staną się ruiną, a naczynia sanktuarium zostaną zabrane do niewoli. Ostatniego z nich zabiję mieczem, nie ucieknie ani jeden, nie przetrwa żaden z nich»".

Według targumisty chwała Pańska (יקרָָ דַיוי":) odchodzi na cherubinie jakby na niebiańskim rydwanie. ${ }^{30} \mathrm{~W}$ wypowiedzi Boga targum znacznie różni się od tekstu masoreckiego. Zapowiedź klęski i zniszczenia są wynikiem braku nawrócenia i powrotu do Tory (אוֹרָּר)

Targumiści często podkreślali wagę modlitwy, którą zgodnie z rabinacką wykładnią uważają modlitwę za substytut ofiar, których nie można już składać po zniszczeniu świątyni. ${ }^{31}$ Modlitwa to klucz do osobistego zbawienia.

Tekst masorecki 6,10:

„(...) «Czy jest jeszcze ktoś z tobą?» Odpowie: «Nikt», i powie: «Cicho!», bo nie można będzie wspominać imienia JHWH".

Targum 6,10:

„(...) «Czy jest z tobą ktoś jeszcze?» Odpowie: «Pomarli». I powie:

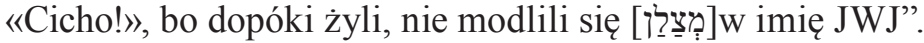

Wprowadzając temat modlitwy do przekładu aramejskiego, targumista odzwierciedla przekonanie, że kara i śmierć mogą być efektem braku modlitwy do Boga.

30 Por. Tg Ez 9,3 i takie samo zastosowanie występujących tu terminów.

31 Por. Oz 14,3b. 
Tam, gdzie jest mowa o prośbie Amosa targumista w sposób naturalny interpretuje słowa prośby wprost jako modlitwę:

Tekst masorecki 7,2:

„, (...) Panie Boże, przebacz, jak może przetrwać Jakub? Przecież jest taki mały".

Targum 7,2:

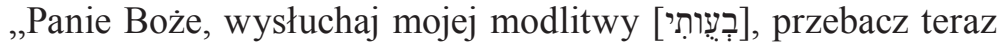

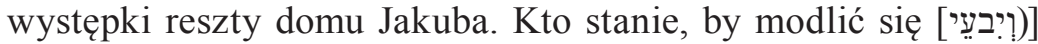
w związku z ich grzechami, bo też są rozproszone?” (zob. też 7,5).

W tekście masoreckim: „Jak może przetrwać Jakub? Bo jest za mały". W targumie wersja tego fragmentu wiersza powtarza się niemal dosłownie w w. 5. Tekst masorecki obu wierszy jest prawie identyczny, chociaż w. 5 ma czasownik ,powstrzymaj się”, „zaniechaj”

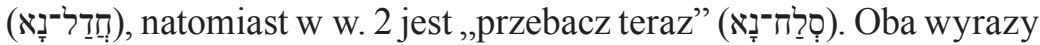
targum tłumaczy za pomocą ,przebacz” (שָׁבוֹק). W Targumie Am 6,10 była mowa o konsekwencjach zaniechania modlitwy. Natomiast w 7,2 targumista mówi o modlitwie wstawienniczej ze względu na sytuację „domu Jakuba”, rozproszonego za popełnione grzechy. ${ }^{32}$

Targum Księgi Amosa, podobnie jak księga biblijne przekazuje nadzieję na przyszłość i mówi o przyjściu dni, kiedy zostanie odbudowany dom Dawida. Jednak Targum mówi wyraźnie, że Bóg odbuduje królestwo Dawida i miasta oraz ustanowi od nowa zgromadzenie sprowadzi liczne wojska oraz sprowadzi wygnanych.

Targum Am 9,11-12 i 14-15:

„11 «W owym czasie podniosę królestwo domu [TM: „szałas”] Dawida, które upadło, odbuduję ich miasta [TM: ,załatam wyłomy”] i od nowa podniosę ich zgromadzenia [TM: „zniszczenia”, „,ruiny”]. Będzie władać nad wszystkimi królestwami i zniszczy, i sprowadzi koniec na wielkość wojsk; lecz zostanie odbudowane i ustanowione [TM: ,ja je odbuduję"] na nowo jak za dawnych dni, ${ }^{12}$ tak żeby

32 Zob. K. J. C a th c a r t, R. P. G o r d o n, The Targum of the Minor Prophets, s. 90 . 
dom Izraela nazywany Moim imieniem mógł posiąść resztę Edomu i wszystkie narody» - mówi Pan. «Oto, co uczynię. (...) ${ }^{14}$ Sprowadzę wygnanych [TM: przywrócę pomyślność] spośród Mego ludu Izraela. Odbudują zburzone miasta i zamieszkają w nich, zasadzą winnice i pić będą wino, założą ogrody i będą spożywać ich owoce. ${ }^{15}$ I ustanowię [TM: zasadzę] ich na tej ziemi i już nigdy nie zostaną uprowadzeni [TM: ,wyrwani”] ze swego kraju, który im dałem»mówi Pan, wasz Bóg".

We opisie tym obraz odbudowy ruin zostaje oddany przez targumistę jako odbudowa miast, ale także odbudowa zgromadzenia. Wprowadzenie bezpośrednio odwołanie do królestwa domu Dawida, które ma panować nad wszystkimi królestwami oraz pojawienie się licznych wojsk w targumie nabiera mocnego wydźwięku mesjanistycznego.

W przekładzie tego fragmentu występują także inne zmiany, które wprowadzono ze względu na jasność tekstu, tak jak to jest w w. 12, gdzie targumista dodaje zwrot „dom Izraela”, aby zapobiec implikacjom wynikającym z tekstu masoreckiego w związku z obcymi narodami. Mogą one być podyktowane także regułami, odnoszącymi się do mówienia o Bogu, zob. w. 15, w którym targumista zamienia czasowniki „zasadzić”, „wyrwać, „wykorzenić” z tekstu masoreckiego, na „ustanowić” „uprowadzić”, aby uniknąć przypisywania Bogu ludzkich działań typu „sadzenie” lub „wykorzenianie”.

Przedstawiona powyżej analiza nie wyczerpuje wszystkich zmian, jakie zostały wprowadzone w przekładzie aramejskim Księgi Amosa. W artykule przedstawione głównie te zmiany, które odzwierciedlają odmienny sposób odczytania tekstu biblijnego w kontekście żydowskiej myśli teologicznej. W wielu przypadkach wymienione przykłady nie są czymś specyficznym dla omawianego targumu, lecz odzwierciedlają poglądy zawarte w całym Targumie Jonatana oraz pozostałych przekładów ksiąg biblijnych. 